\title{
MORE PROFITABLE RICE VARIETIES CROWD BENEFICIAL LANDRACES OUT
}

\author{
Krishna Prasad Pant, PhD ${ }^{1}$
}

\begin{abstract}
The study compares gross revenues from modern rice varieties and landraces and valuates different useful traits of rice landraces to demonstrate an empirical methodology for biodiversity valuation. A sample of 200 rice growers in hills and plain area was surveyed for commercialization of agro-biodiversity project. For estimating the value put by the consumers on different rice traits a hedonic pricing model was used that disaggregates the prices paid by the consumers for different useful traits of rice. The results show that the consumers value aromatic and tasty traits much higher than other traits. As the farmers are earning much lower income from many landraces as compared to that from modern varieties, the farmers are likely to replace them by the modern varieties. The findings of the study will be helpful to prepare market based strategies for rice biodiversity conservation, particularly for the conservation of rice landraces.
\end{abstract}

Key words: Agrobiodiversity, biodiversity-valuation, hedonic-pricing, rice-landrace, traits

\section{BACKGROUND}

Rice biodiversity is a reservoir of rice genetic resources with allelic variations that have vast potential for future rice breeding. The diversity of food plants consists of crop resources that are created and maintained by the farmers as active components of agroecosystems (Brookfield and Padoch, 1994; Vandermeer et al, 1998). Though the need for the conservation of rice biodiversity is agreed by all, the origin of the conflicts for dealing with this issue stems from the rules of division and appropriation of the benefits out of the commercial utilization of the rice genetic resources. Rice being the most important staple food in South and South East Asia, the conservation of the rice diversity and utilization of the diversity for rice breeding are directly related to the food security of this heavily populated part of the world.

Considering the immediate need for addressing food problem, green revolution replacement model of agricultural development is still emphasised whereby landraces are displaced by the so called high yielding and fertilizer responsive modern varieties. As the market supplies high yielding modern varieties of rice, the rational farmers do replace narrow genetic base modern varieties for low productive but rich in other trait landraces they have. A few, genetically uniform, such varieties have replaced genetically variable crop landraces (Brush, 1991; Harlan, 1992). There are many useful traits in landraces that the farmers like. In Nepal, about 53 percent of the farm households continue to grow both modern varieties and landraces simultaneously (Joshi and Bauer, 2006). The farmers generally grow high yielding modern varieties for sales and landraces for family consumption. The farmers having larger size of the rice land demand different high yielding varieties depending on the traits. Their demand for these types is clearly shaped in part as a derived demand from markets, land and soil heterogeneity and in part by the consumption preferences of their families. There is a need to conserve on-farm rice diversity as part of a strategy to conserve crop, rice genetic resources of diverse characteristics. Growing different rice varieties by the farmers to meet different needs is the development approach ${ }^{2}$ of the biodiversity conservation. This approach values,

\footnotetext{
1 Senior Agricultural Economist, MOAC, kppant@yahoo.com.

2 There are other approaches to protect biodiversity, including in-situ conservation through protected area conservation, ex-situ conservation through zoos, aquaria, botanical gardens, seed banks and gene banks.
} 
conserves, develops and markets agro-biodiversity to alleviate the extreme poverty (Bardsley and Thomas, 2003). However, measuring the value of biodiversity is a great challenge. Reid et al. (1993) observed that even the debates on the measurement of biodiversity started in the 1950s and there is no clear consensus about how the value of biodiversity should be measured. Pearce and Moran (1994) examined some aspects of measurement of biodiversity for genetic diversity, species diversity and ecosystem diversity. According to them, the genetic differences can be measured in terms of phenotypic traits, allelic frequencies or dioxy-ribose nucleic acid (DNA) sequences. The measurements of allelic diversity and DNA sequence, however, require high level technical information which is out of the scope of this paper. The study relies on the phenotypic diversity that is based on measures of phenotypes, involving readily measurable practical utility to the consumers and the farmers. For the purpose of the study the consumers of the products are taken as the market for different traits. Consumers while buying rice considers price and its characteristics. The characteristics they search for fall under three catageries. The first is the selection characteristics like colour and shine of the grain, length of the grain and brand name if any. The second is experience characteristics like cooking qualities (expansion in cooking, non-stickyness) and eating qualities (like aroma and taste). The third set is the credence characteristics like percent of protein and quality of starch which are never known to the ordinary consumers. The analysis is based on the selection and experience characteristics of rice landraces. This paper estimates the use values put by communities for rice diversity to demonstrate their importance to policy makers.

\section{METHODOLOGY}

Two districts (Kaski from hill and Bara from Terai Nepal) have been selected purposively considering the richness of the rice varietal diversity. Four villages (Lekhnath and Lumle from Kaski district and Kacharba and Maheshpur from Bara district) with high concentration of the landraces ${ }^{1}$ and high yielding modern varieties have been identified by a key informant survey (Pant, 2009). Considering the variations in the study variable, the rice landraces and budget available for the study a sample of 200 households was selected randomly using simple random sampling method without replacement. The pre-tested questionnaire was administered to conduct the survey.

The basic theoretical foundation of the estimation is that the rice consumers pay for different desirable traits of rice as different bundles of the commodity. The capacity of the modern breeding technology that can disaggregate and aggregate different traits in a variety has made this analysis relevant. Empirical estimation of use value of rice genetic diversity is done following hedonic pricing method (HPM) ${ }^{2}$. Early applications of the hedonic pricing methods start from 1920s on farm land characteristics. The first reference of hedonic modeling is found in price differences in fresh vegetables (Waugh, 1928). The basic foundation for application of hedonic pricing method is the expectation that property prices are an increasing function of the environmental quality given the characteristics of the commodity. This paper analyses that market traits of rice rather than its environment related properties. The theoretical foundation of HPM for integrating characteristics in modeling is further elaborated and formalized by Lancaster (1966). According to him environmental characteristics like air or water quality affect the price of land either as a producer good or as a consumer good. The hedonic pricing literature on environmental

1 Landraces include farmers' traditional varieties that farmers have produced and maintained themselves, often for many generations, as well as former high yielding varieties that had been bred and were then released more than 15 years and that have since become incorporated into farmers' own seed production (Almekinders and Louwaars 1999; Cleveland and Soleri 2002).

2 Hedonic pricing method is used to desaggregate the price of a product to different traits the product is having. Here in this paper, the HPM is used for dividing the price paid by the consumers to a kg of rice into its differrent characteristics like aromatic, tasty, suitable for beaten rice and like. 
valuation are built upon the input characteristic modeling of the utility maximizing HPM, as originally presented by Griliches (1966), Lancaster (1966) and as adapted further by Ladd and Savannut (1976). Ridker (1967) is the first to use this method on environmental goods for estimating marginal value of air quality in residential areas. The equilibrium is achieved when the variation in price reflects the variation in the attributes under the condition of full information. For estimating the use value given by the consumers attributable to major traits of rice varieties, the farmgate price of different landraces and varieties of rice was regressed with tasty trait, aromatic, suitability for bitten rice (flatened rice used for snacks), good for latte and siroula (local dishes for special occasions), medicinal uses, used in ceremony, expansion in cooking, good storage, milling percent, Terai area, and main season crop.

\section{VALUATION OF RICE GENETIC DIVERSITY}

The sample farmers of 200 households are growing 78 rice verieties altogether. The relative abundance of these varieties is presented in Table 1. BG-1442, Basmati, Sona Masuli and Anadhi are the most popular four varieties grown by more than 20 percent of the farmers. Farmers plant each variety separately on different plots or sometimes in the different parts of the same plot. On average, each farmer is growing 4.62 varieties of rice every year. Owing to the small size of the land holding, each variety on average commands very small area. The precious landraces are unable to compete with other commercially grown modern varieties. These varieties are thriving in the farmers' field only due to their special phenotypic characteristics that are controlled by the respective genes. To protect such genes from extinction, there is a need to understand the value of these genes and make the landraces beneficial to the farmers to stay on the farmers' fields.

The main reasons for very small area under many landraces are that their productivities are low and the prices are not high enough to compensate the lower productivity in comparision to the modern rice varieties (Fig.1). The average gross revenue ${ }^{1}$ from the landraces is Rs 19,904 per hectare as against Rs 26,622 from modern varieties (Annex 1 and 2). It is clear that the gross return from many landraces is about one third of the gross return from other competing modern varieties. The landraces are surviving in the field of the farmers only due to their typical characteristics that modern varieties can not fulfill. It shows that the typical landraces with unique useful genes are finding tough replacement challenge from modern rice varieties to survive in situ. Some more productive rice landraces like Meghdoot and Basmati appear to be able to compete with modern varieties due to their higher prices, but such varieties need good quality land to produce that limit the farmers to expand their areas. Other many varieties that seem to be less competitive are at the verge of extinction. The policy should either go for ex situ conservation or understand the value of these landraces to the society and find market means of conserving them in situ.

For the purpose of estimating the value, the society puts on different traits of rice varieties, a hedonic pricing model is fitted with the market price of paddy rice ${ }^{2}$. The phenotypic characteristics like tasty to eat, aromatic, good for latte and siroula (local snacks popular in particular occasions), used in ceremony and medicinal properties are preferred by the consumers. It is hypothesized that for each of these preferred traits, consumers pay certain amount. As the price is taken for fresh harvest of paddy rice, the milling percent (recovery of milled rice) is also a concern for the buyer. It is hypothesized that the higher the milling percent the higher the buyer will pay keeping all other traits

\footnotetext{
${ }^{1}$ Cost of production of the landraces is not included in the paper as it does not differ much from that of the modern varieties.

2 The term "paddy rice" in thisw paper connotes unmilled rice. Milling $100 \mathrm{~kg}$ of paddy rice produces on an average $63 \mathrm{~kg}$ of milled rice. The "milled rice" is generally termed as "rice". The recovery percent from paddy rice to milled rice is called milling percent.
} 
constant. Geographical area plain (Terai) is fitted to catch the fixed effects of hills and plains. It is also hypothesized that the main season paddy rice fetches higher price than the summer season paddy rice. Though some of the traits appear to be not mutually exclusive, they are used separately as long as there is no risk of multicollinearity.

Table 1: Relative abunadance of rice varities

\begin{tabular}{|c|c|c|}
\hline $\begin{array}{l}\text { Relative } \\
\text { abundance }{ }^{1}(\%)\end{array}$ & $\begin{array}{l}\text { Name of the modern rice } \\
\text { variety }\end{array}$ & Name of rice landrace \\
\hline 40 to 50 & BG-1442 (1) & 0 \\
\hline 30 to 40 & 0 & Basmati (1) \\
\hline 20 to 30 & Sona Masuli (1) & Anadhi (1) \\
\hline 10 to 20 & $\begin{array}{l}\text { Mansuli, China-4 and Sabitri } \\
\text { (3) }\end{array}$ & $\begin{array}{l}\text { Kathe, Anga, Meghdoot, Jetho Budho, Pahele, } \\
\text { Sotwa, Rekshali, Ekle, Dhudhraj and Harinkar } \\
\text { (10) }\end{array}$ \\
\hline Less than 10 & $\begin{array}{l}\text { Lumle-2, Chaite-1, BGAR-4, } \\
\text { Ghaiya -2, Radha-7, Janaki, } \\
\text { Radha-9, Barkhe-2, } \\
\text { Machhapuchhre, Khumal -4, } \\
\text { Chhomrong, Jaya, } \\
\text { Biramful*Himali, Ekle hybrid, } \\
\text { Ekle*KY, HY-6264, IR-6465, } \\
\text { Mansara Hybrid, Sano Gurdi } \\
\text { Hybrid, Sano Gurdi * NR, } \\
\text { Thulo Gurdi Hybrid and Thulo } \\
\text { gurdi*NR (22) }\end{array}$ & $\begin{array}{l}\text { Rate, Kalopatle, Gurdi, Biramful, Chhatraj, } \\
\text { Mutmur, Rato Anadi, Bayarni Jhinuwa, Chhote, } \\
\text { Jerneli, Mansara, Seto Anadi, Darmali, } \\
\text { Madhesi, Manamuri, Natwar, Budho Sigdeli, } \\
\text { Nakhisaro, Kaskeli Thude, Gauria, Kathe } \\
\text { Gurdi, Ranga, Sokan, Thulo Gurdi, Sathi, } \\
\text { Gajale Gurdi, Madhumala, Masula, Philipes, } \\
\text { Lamjunge, Deurali, Sano Gurdi, Seto Gurdi, } \\
\text { Rato Darmali, Deupure Kathe, Kaskeli Kathe, } \\
\text { Bhelasaro, Lahare Gurdi and Bhalu (39) }\end{array}$ \\
\hline Total & (27) & (51) \\
\hline
\end{tabular}

Table 2: Comparision of the yield of and gross revenues from modern varieties and landraces

\begin{tabular}{|c|c|c|}
\hline $\begin{array}{l}\text { Gross revenues } \\
\text { (Rs/ha) }\end{array}$ & Modern varieties & Landraces \\
\hline Over 50,000 & Sona Masuli & 0 \\
\hline 40,000 to 50,000 & BG-1442 & Meghdoot, Basmati \\
\hline 30,000 to 40,000 & BGAR-4, China-4, Mansuli & Harinkar, Chhatraj, Dhudhraj, Bayarni Jhinuwa \\
\hline 20,000 to 30,000 & $\begin{array}{l}\text { Sabitri, Barkhe-2, Radha- } \\
\text { 9, Ghaiya -2, Jaya, } \\
\text { Chaite-1, Radha-7 }\end{array}$ & $\begin{array}{l}\text { Sotwa, Madhumala, Seto Anadi, Biramful, Jetho } \\
\text { Budho, Ekle, Gurdi, Rato Anadi, Seto Gurdi, } \\
\text { Anadhi, Gauria, Natwar, Mutmur, Pahele, } \\
\text { Gajale, Gurdi }\end{array}$ \\
\hline 10,000 to 20,000 & $\begin{array}{l}\text { Khumal -4, Masula, } \\
\text { Janaki, Lumle-2, } \\
\text { Chhomrong }\end{array}$ & $\begin{array}{l}\text { Ranga, Machhapuchhre, Nakhisaro, Kathe } \\
\text { Gurdi, Philipes, Darmali, Madhesi, Chhote, } \\
\text { Manamuri, Bhalu, Kalopatle, Jerneli, Rato } \\
\text { Darmali, Mansara, Anga, Budho Sigdeli, } \\
\text { Lamjunge, Rate, Rekshali, Deurali, Kaskeli } \\
\text { Thude, Sokan, Kathe, Kaskeli Kathe, Deupure } \\
\text { Kathe, Lahare Gurdi }\end{array}$ \\
\hline Less than 10,000 & 0 & Sathi, Thulo Gurdi, Bhelasaro, Sano Gurdi \\
\hline
\end{tabular}

The philosophy behind hedonic pricing model is that nobody pays for a commodity but the people pay for the embedded bundles of utilities of a product. The utilities may or may not be separable. The average price paid by the market to the fresh harvest of paddy rice is Rs 1,034 per quintal ranging from Rs 500 to 2,400 . If it is assumed that all the farmers are getting equal market opportunity, the variation in the price is due to the difference in the

\footnotetext{
1 The Relative abundance is measured as the percent of the households growing that variety or landrace.
} 
quality, that is, the bundle of traits. The observation used in the model is the landraces and modern varieties grown in each of the sample households.

For each landrace and modern variety the combination of the traits is different and the price fetched is also different. Thus, the total number of the observations in the sample of 200 households is 932 .

Table 3: Use value of major traits of rice landraces $(n=932)$

\begin{tabular}{llrrc}
\hline & \multicolumn{1}{c}{ Variables } & Coefficient $^{1}$ & \multicolumn{1}{c}{ Mean } & Unit \\
\hline 1 & Price of paddy rice & Dependent & 1033.87 & Rs/quintal \\
2 & Tasty & $49.22^{* *}$ & 0.61 & dummy \\
3 & Aromatic & $292.93^{* * *}$ & 0.19 & dummy \\
4 & Good for latte \& siroula & $107.61^{* * *}$ & 0.08 & dummy \\
5 & Used in ceremony & $130.83^{* * *}$ & 0.18 & dummy \\
6 & Milling percent squared & $-0.05^{* * *}$ & 3931.61 & percent \\
7 & Terai area & $164.27^{* * *}$ & 0.48 & dummy \\
8 & Main season paddy rice & $76.47^{* * *}$ & 0.92 & dummy \\
9 & Year of growing squared & $0.02^{* * *}$ & 850.67 & year \\
10 & Non agriculture income & $0.14^{* * *}$ & 82.37 & Rs 1000 \\
11 & Constant & $924.91^{* * *}$ & & \\
& F( 9, 922) & $74.02^{* * *}$ & & \\
& Adjusted $\mathrm{R}^{2}$ & 0.414 & & \\
\hline
\end{tabular}

Source: Household survey 2006.

The results of linear hedonic model fitted over the above data are presented in Table 3 along with the mean value of the variables. The estimates show that the consumers pay Rs 49 per quintal for a tasty trait. This estimated coefficient is 4.76 percent of total price of paddy rice. The estimate is highly significant. It can be inferred that by conserving the landrace with this trait and keeping alive the potential of incorporating this trait to other rice varieties, the potential benefits will come from increasing value of paddy rice production by nearly five percent. Similarly, for the aromatic trait, the consumers are ready to pay nearly Rs 293 per quintal. This is nearly 28 percent of the average price of the paddy rice. If this aromatic trait is lost, the potential financial loss to the society would be 28 percent of the total value of paddy rice produced. This is a huge figure and sufficient to warrant conservation measures. Though the analysis is generalized, there are so many specific traits in the bundle of aromatic rice. Each of such traits is worth conserving. The rice landraces having traits suitable for snacks like latte and siroula can fetch higher price by Rs 107 per quintal. Similarly, the traits suitable for using in ceremonies are valued higher by Rs 131 than other varieties.

The result shows that the higher the milling percent (squared value) the lower the consumers are willing to pay. Though the result is significant it is very small. This can not be explained under the assumptions of rational consumers and full information. This is because the milling percent is experience good that is not known to the buyers at the time of bidding a price. The farmers in plain region are getting higher price of paddy rice for similar quality as compared to the farmers in hill region. This is due to better transportation and communication facilities in plain areas for better market connectivity. The independent variables explain nearly 41 percent variations in the price of paddy rice.

\footnotetext{
${ }^{1}$ Note: ${ }^{* * *}$ for $1 \%$ level of significance, ${ }^{* *}$ for $5 \%$ level of significance and ${ }^{*}$ for $10 \%$ level of significance.
} 


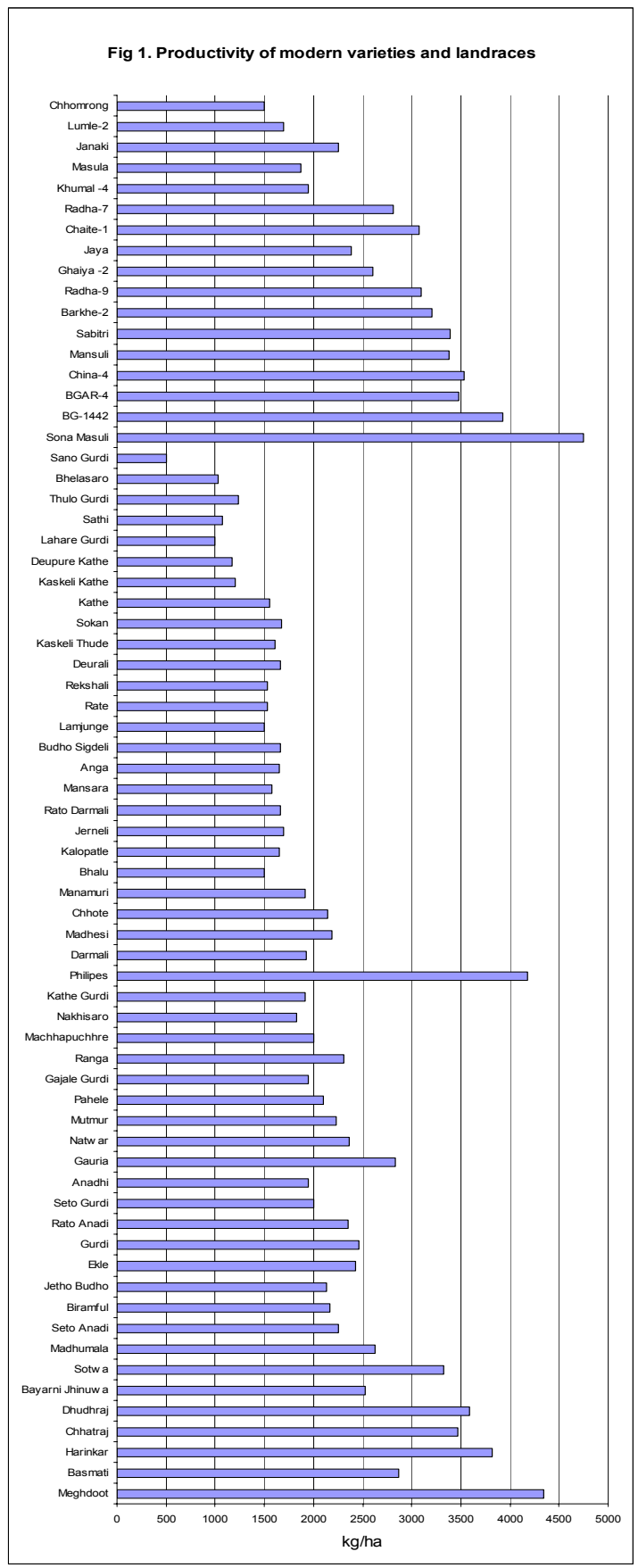

Fig 2. Gross revenues from modern varieties and landraces

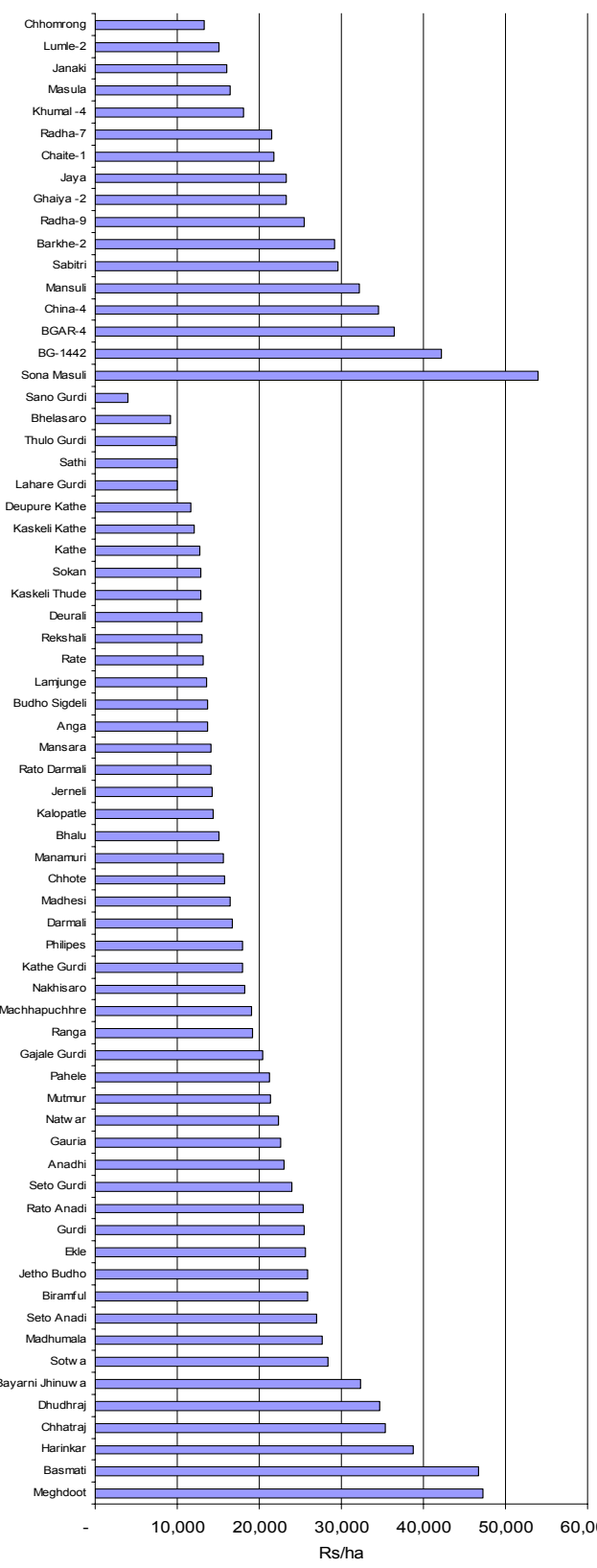


Rice in Nepal occupies more than a half share of principal food crops. On an average four million tons of paddy rice is produced every year (GON, 2007) with an estimated value of Rs 41.4 billion using the price estimated from the survey (Rs 10,340 per ton) as the representative at the national level. It means the aromatic traits of rice generate an extra Rs 11 billion per annum for Nepal and tasty traits over two billion rupees. However, there are different landraces with different degree of aroma and different level of taste. A separate study is required to quantify the level of such traits and find the value for each level of aroma and taste. The analysis apportioned the price paid by the consumers to the value given to different traits. It means protecting each of the preferred trait roughly increased value to the society by certain amount. For example, about one fourth of the value of paddy rice produced can be the value of aromatic trait. This includes use values of rice that arise from the actual use of rice. This use value consists of direct use value of the rice consumption by the households and seeds used by the farmers. The non-use value of rice landrace is not included in this analysis.

\section{CONCLUSIONS}

The hedonic property valuation analysis apportioned the price paid by the consumers to the value they give to different traits of rice. The study concludes that protecting each of the preferred trait increases the value to the society to a large extent. For instance, the value of the aromatic trait of Basmati or other local landraces can be about one fourth of the value of the paddy rice produced. The aromatic traits of rice have values of about Rs 11 billion and tasty traits over two billion rupees per annum. This estimation of value includes only the use values of the rice that arise from the actual use consisting the direct use value from consumption by the households and option values generated by an individual's willingness to pay to protect the rice landraces for the future use in rice breeding. The gross returns from many landraces are much lower than those from the modern varieties. For both moral and pragmatic reasons, it is essential either to compensate local poor farmers for maintaining low productive rice landraces or make these landraces better income generating than the narrow genetic base modern varieties that are available to them.

\section{REFERENCES}

Almekinders, C. J. M. and N. Louwaars, 1999. Farmers' seed production: New approaches and practices. London: Intermediate Technology.

Anderson, R. J. and T. D. Crocker, 1971. Air pollution and residential property values. Urban Studies, 8: 171-80.

Anderson, R. J. and T. D. Crocker, 1972. Air pollution and property values a reply. Review of Economics and Statistics, 54: 470-73.

Bardsley, D. and I. Thomas, 2003. In situ agro-biodiversity conservation for regional development in Nepal. Geojournal, 62:27-39

Brookfield, H. and C. Padoch, 1994. Appreciating agrodiversity: a look at the dynamism and diversity of indigenous farming practices. Environment, 36:7-11.

Brush, S. B., 1991. A farmer-based approach to conserving crop germplasm. Economic Botany, 45:153165.

Cleveland, D. A., and D. Soleri, 2002. Collaborative Plant Breeding Integrating Farmer and Scientist Knowledge and Practice. Wallingford: CAB International.

Freeman, A. Myrick III, 1974a. Air pollution and property values a further comment. Review of Economics and Statistics, 56:454-56.

Freeman, A. Myrick III, 1974b. On estimating air pollution control benefits from land value studies. Journal of Environmental Economics and Management, 1:74-83.

GON, 2007. Economic Survey 2005-06. Ministry of Finance, Government of Nepal, Kathmandu 
Griliches, Zvi, 1966. Hedonic Price Indexes for Automobiles: An Econometric Analysis of Quality Change. In: A. Zellner (ed.), Readings in Economics, Statistics, and Econometrics, pp.103-130. Boston: Little Brown and Company.

Haab, T.C. and K. E. McConnell, 2002. Valuing Environmental and Natural Resources, Edward Elgar, Northampton.

Harlan, J.R., 1992. Crops and Man, 2nd edition. American Society of Agronomy, Madison WI.

Horowitz, J. L., 1986. Bidding models of housing markets. Journal of Urban Economics, 20:168-90.

Joshi, G. R. and S. Bauer, 2006. Determinants of rice variety diversity on household farms in terai region of Nepal. Contributed papper presented at the IAAE Conference, Gold Qoast, Australia, August 12-18.

Kanemoto, Y., 1988. Hedonic prices and the benefits of public projects. Econometrica, 56(4):981-89.

Ladd, G. W., and V. Savannunt, 1976. A model of consumer goods characteristics. Amer. J. of Agric. Econ., 58:504-510.

Lancaster, K., 1966. A new approach to consumer theory. J. Polit. Econ., 74:132-157.

Lind, R. C., 1973. Spatial equilibrium, the theory of rents, and the measurement of benefits from public program. Quarterly Journal of Economics, 87: 188-207.

Murdoch, J. C. and M. J. Thayer, 1988 Hedonic price estimation of variable urban air quality. Journal of Environmental Economics and Management, 15(2): 143-46.

Nelson, J. P., 1978. Residential choices, hedonic prices and the demand for urban air quality. Journal of Urban Economics, 5(3): 357-69.

Pant, K. P., 2009. Price-based valuation of rice genetic diversity in Nepal. Paper presented at the International Association of Agricultural Economists Conference, Beijing, China, August 16-22, 2009.

Pearce, D. and D. Moran, 1994. The Economic Value of Biodiversity. London: Earthscan.

Pines, D. and Y. Weiss, 1976, Land improvement projects and land values. Journal of Urban Economics, 3:1-13.

Polinsky, S. A. Mitchell and S. Shavell, 1976. Amenities and property values in a model of an urban area. Journal of Public Economics, 5:119-29.

Portney, P. R., 1981. Housing prices, health effects and valuing reduction in risk of death. Journal of Environmental Economics and Management, 8:72-78.

Reid, W.V., S.A. Laird, C.A. Meyer, R.S.A. Gamez, D.H. Janzen, M.A. Gollin and C. Juma, 1993. A new lease on life. In: W.V. Reid et al. (eds.), Biodiversity Prospecting: Using Genetic Resources for Sustainable Development. World Resources Institute. Washington, DC.

Ridker, Ronald G., 1967. Economic Costs of Air Pollution Studies in Measurement Praeger. New York.

Vandermeer J., M. van Noordwijk, J. Anderson, C. Ong and I. Perfecto, 1998. Global change and multispecies agroecosystems: Concepts and issues. Agric. Ecosystems Environ, 67(1):1-22.

Waugh, F., 1928. Quality factors influencing vegetable prices, Journal of Farm Economics, 10:185-96.

\section{ACKNOWLEDGEMENT}

The author is highly grateful to the anonymous reviewer for the excellent comment on the manuscript. The author is thankful to Mr. J. C. Gautam for coordinating the data collection activities for the study. The author is also thankful to the participants of the International Association of Agricultural Economists Conference, Beijing, China, August 16-22, 2009, who provided useful comments on the earlier version of the paper. 
Annex 1: Yield of and gross revenues from modern varieties of rice

\begin{tabular}{llrrrr}
\hline & Variety & Frequency & Yield $(\mathrm{kg} / \mathrm{ha})$ & Price $(\mathrm{Rs} / \mathrm{kg})$ & Gross revenue (Rs/ha) \\
\hline 1 & Sona Masuli & 59 & 4,752 & 11.36 & 53,984 \\
2 & BG-1442 & 89 & 3,928 & 10.74 & 42,197 \\
3 & BGAR-4 & 7 & 3,474 & 10.50 & 36,487 \\
4 & China-4 & 28 & 3,537 & 9.77 & 34,566 \\
5 & Mansuli & 29 & 3,378 & 9.52 & 32,154 \\
6 & Sabitri & 28 & 3,396 & 8.73 & 29,642 \\
7 & Barkhe-2 & 4 & 3,209 & 9.09 & 29,179 \\
8 & Radha-9 & 4 & 3,096 & 8.22 & 25,466 \\
9 & Ghaiya -2 & 7 & 2,604 & 8.96 & 23,332 \\
10 & Jaya & 2 & 2,388 & 9.75 & 23,284 \\
11 & Chaite-1 & 12 & 3,069 & 7.08 & 21,736 \\
12 & Radha-7 & 6 & 2,810 & 7.67 & 21,559 \\
13 & Khumal -4 & 3 & 1,944 & 9.27 & 18,028 \\
14 & Masula & 2 & 1,874 & 8.78 & 16,451 \\
15 & Janaki & 4 & 2,250 & 7.15 & 16,083 \\
16 & Lumle-2 & 18 & 1,694 & 8.90 & 15,088 \\
17 & Chhomrong & 3 & 1,500 & 8.89 & 13,333 \\
& Average & 305 & 2,877 & 9.08 & 26,622 \\
\hline
\end{tabular}

Annex 2: Yield of and gross revenues from landraces of rice

\begin{tabular}{|c|c|c|c|c|c|c|c|c|c|}
\hline Landraces & $\begin{array}{l}\text { Fre- } \\
\text { quency }\end{array}$ & $\begin{array}{l}\text { Yield } \\
\text { (kg/ha) }\end{array}$ & $\begin{array}{l}\text { Price } \\
\text { (Rs/kg) }\end{array}$ & $\begin{array}{l}\text { Gross } \\
\text { revenue } \\
\text { (Rs/ha) }\end{array}$ & Landraces & $\begin{array}{l}\text { Fre- } \\
\text { quency }\end{array}$ & $\begin{array}{l}\text { Yield } \\
\text { (kg/ha) }\end{array}$ & $\begin{array}{l}\text { Price } \\
\text { (Rs/kg) }\end{array}$ & $\begin{array}{l}\text { Gross } \\
\text { revenue } \\
\text { (Rs/ha) }\end{array}$ \\
\hline Meghdoot & 33 & 4,345 & 10.86 & 47,193 & Darmali & 7 & 1,929 & 8.67 & 16,714 \\
\hline Basmati & 75 & 2,872 & 16.29 & 46,780 & Madhesi & 6 & 2,183 & 7.54 & 16,467 \\
\hline Harinkar & 21 & 3,822 & 10.15 & 38,802 & Chhote & 7 & 2,143 & 7.33 & 15,714 \\
\hline Chhatraj & 9 & 3,467 & 10.20 & 35,348 & Manamuri & 6 & 1,917 & 8.13 & 15,583 \\
\hline Dhudhraj & 23 & 3,585 & 9.66 & 34,620 & Bhalu & 1 & 1,500 & 10.00 & 15,000 \\
\hline Bayarni & 7 & ,524 & 12.78 & 32,267 & Kalopatle & 14 & 1,653 & 8.69 & 14,361 \\
\hline Sotwa & 28 & 3,329 & 8.53 & 28,406 & Jerneli & 7 & 1,693 & 8.38 & 14,186 \\
\hline Madhumala & 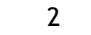 & 2,627 & 10.55 & 27,701 & Rato Darmali & 1 & 1,667 & 8.50 & 14,167 \\
\hline Seto Anadi & 7 & 2,252 & 12.00 & 27,020 & Mansara & 7 & 1,576 & 8.91 & 14,046 \\
\hline Biramful & 9 & 2,167 & 11.97 & 25,944 & Anga & 35 & 1,653 & 8.31 & 13,730 \\
\hline Jetho Bud & 31 & 2,129 & 12 & 25,840 & Budho Sigdeli & 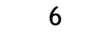 & 1,667 & 8. & 13,667 \\
\hline Ekle & 24 & 2,428 & 10.55 & 25,612 & Lamjunge & 2 & 1,500 & 9.00 & 13,500 \\
\hline Gurdi & 10 & 2,467 & 10.34 & 25,500 & Rate & 19 & 1,526 & 8.58 & 13,096 \\
\hline Rato A & 0 & 2,356 & 10.77 & 25,375 & Reksh & 27 & 1,528 & 8.54 & 13,051 \\
\hline Seto Gurdi & 1 & 2,000 & 12.00 & 24,000 & Deurali & $?$ & 1,667 & 7.80 & 13,000 \\
\hline Anadhi & 53 & 1,945 & 11.81 & 22,975 & askeli Tr & 4 & 1,604 & 8.06 & 12,933 \\
\hline Gauria & 3 & 3 & 8.00 & 22,667 & an & 3 & 1,677 & 7.64 & 12,822 \\
\hline Natwar & 6 & 2,367 & 9.4 & 22,286 & Kathe & 37 & 1,554 & 8.19 & 12,734 \\
\hline Mutmur & 0 & 2,228 & 9.58 & 21,341 & Kaskeli r & 1 & 1,200 & 10.00 & 12,000 \\
\hline Pahele & 30 & 2,101 & 10.10 & 21,216 & Deupure Kathe & 1 & 1,167 & 10.00 & 11,667 \\
\hline Gajale Gurdi & 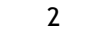 & 1,950 & 10.46 & 20,400 & Lahare Gurdi & 1 & 1,000 & 10.00 & 10,000 \\
\hline Ranga & 3 & 2,308 & 8.31 & 19,184 & & 3 & 1,075 & 9.26 & 9,950 \\
\hline Mach & ? & & & & Thulo & 3 & 1,233 & 8.00 & 9,867 \\
\hline Nakhi & 4 & 1,828 & 10.00 & 18,284 & Bhela & 1 & 1,023 & 9.00 & 9,211 \\
\hline Kathe Gurdi & 3 & 1,911 & 9.40 & 17,956 & Sano Gurdi & 1 & 500 & 8.00 & 4,000 \\
\hline Philipes & 2 & 4,179 & 4.29 & 17,910 & Average & & 2,076 & 9.50 & 19,904 \\
\hline
\end{tabular}

